\title{
MIR137 wt Allele
}

National Cancer Institute

\section{Source}

National Cancer Institute. MIR137 wt Allele. NCI Thesaurus. Code C82086.

Human MIR137 wild-type allele is located in the vicinity of $1 \mathrm{p} 21.3$ and is 101 bases in length. This allele, which encodes MIR137 pre-miRNA, plays a role in the regulation of gene expression. Alteration in the expression of this gene is associated with the development of oral squamous cell carcinoma, non-small cell lung cancer and glioblastoma multiforme. 